\title{
Carbasugar analogues of galactofuranosides: $\alpha-O$-linked derivatives
}

Jens Frigell ${ }^{1}$ and lan Cumpstey ${ }^{* 1,2, \S}$

\section{Full Research Paper}

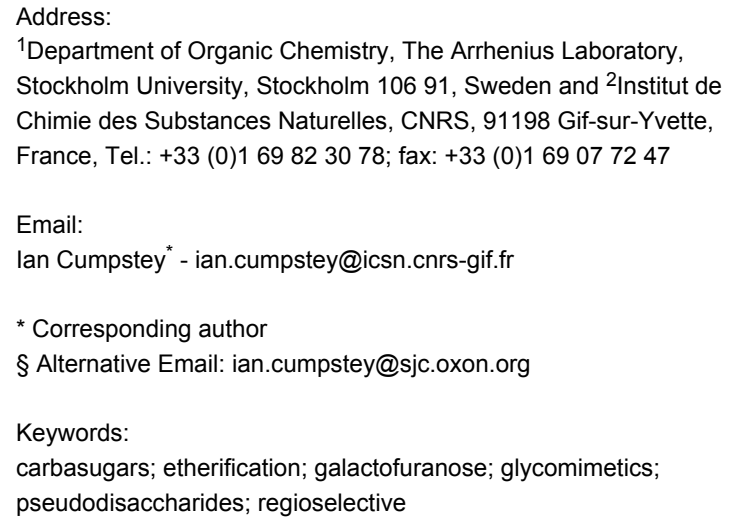

\begin{abstract}
Using an indirect method, we have synthesised $\alpha$-linked carbasugar analogues of galactofuranosides for the first time. Ring opening of a $\beta$-talo configured carbasugar 1,2-epoxide by alcohol nucleophiles under Lewis acidic conditions proceeded with very good regioselectivity to give $\alpha$-talo configured $\mathrm{C} 1$-substituted ethers with a free $\mathrm{OH}$-group at the $\mathrm{C} 2$ position. Inversion of configuration at $\mathrm{C} 2$ by an oxidation-reduction sequence gave the $\alpha$-galacto configured carbahexofuranose $\mathrm{C} 1$ ethers. A carbadisaccharide corresponding to the $\operatorname{Gal} f(\alpha 1 \rightarrow 3) \operatorname{Man} p$ substructure from Apodus deciduus galactomannan was synthesised to exemplify the method.
\end{abstract}

\section{Introduction}

Galactofuranose is found in nature as a component of glycoconjugates in many microorganisms $[1,2]$. Galactofuranosides with the $\alpha$ configuration are rather less common than their $\beta$-linked anomers, from which they are distinguished by their ${ }^{13} \mathrm{C} \mathrm{C} 1$ chemical shifts $(\alpha, 103.8 \mathrm{ppm} ; \beta, 109.9 \mathrm{ppm}$ for the methyl glycosides) [3], and ${ }^{3} J_{1,2}{ }^{1} \mathrm{H},{ }^{1} \mathrm{H}$ coupling constants $(\alpha, 4 \mathrm{~Hz} ; \beta$, $2 \mathrm{~Hz}$ ) [4]. Nevertheless, $\alpha$-galactofuranosides occur as components of a number of oligosaccharides, including plant polysaccharides [5], fungal cell wall polysaccharides [6], glycolipids from thermophilic bacteria [7] and glycosphingolipids from marine sponge (agelagalastatin) [8]. Moreover, the precursor to $\beta$-galactofuranosides and the substrate for galactofuranosyltransferases is UDP-galactofuranose, which has an $\alpha$ configuration [1,2]. Modified, hydrolytically stable analogues of galactofuranosides could find application in the design and synthesis of potential inhibitors of the enzymes involved in the biosynthesis of galactofuranose-containing glycoconjugates.

We have recently developed what appears to be a general route towards carbasugar analogues of $\beta$-galactofuranosides [9]. In our approach, alcohol nucleophiles attack an $\alpha$-galacto carbasugar 1,2-epoxide 1 (Figure 1) under Lewis acidic conditions 
with excellent regioselectivity for attack at $\mathrm{C} 1$. The regioselectivity may be rationalised by steric and electronic arguments: $\mathrm{C} 1$ is more accessible than $\mathrm{C} 2$ due to the absence of a neighbouring bulky group, the $\mathrm{C} 3$ benzyl ether. $\mathrm{C} 1$ is more electrophilic than $\mathrm{C} 2$; it is better able to sustain partial positive charge under Lewis acid coordination due to the absence of a neighbouring electron-withdrawing group, the $\mathrm{C} 3$ benzyl ether.
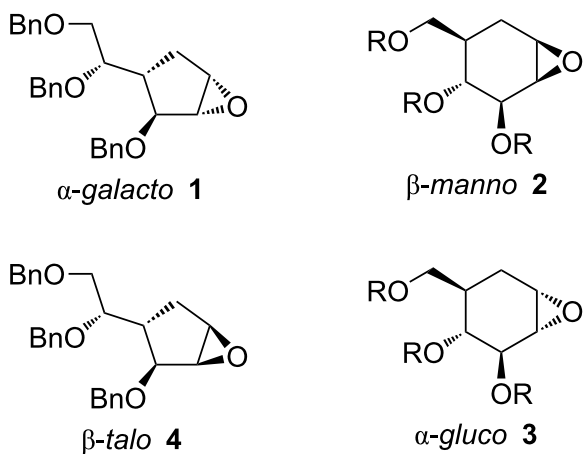

Figure 1: Structures of carbapyranose and carbafuranose 1,2-epoxides.

Ogawa has extensively used epoxide-opening reactions as a coupling method to access $N$ - and $O$-linked pseudodisaccharides based on carbapyranoses [10]. The epoxides were opened by amines in uncatalysed reactions, or by alcohols under Lewis acidic, but more usually basic, conditions. An important general feature of epoxide opening in 6-membered rings is the tendency for trans-diaxial ring opening [11]. The existing substituents on the cyclohexane ring favour one of the two possible half-chair conformations $\left({ }^{4} H_{5}\right.$ for $\mathbf{1}$ and 2). The principle of microscopic reversibility requires an antiperiplanar relationship between the nucleophile and the epoxide oxygen in the product immediately after reaction. From a given half-chair conformation of the epoxide, nucleophilic attack results in either a chair (with the substituents trans-diaxial) or a skewboat conformation, which must rearrange to give the diequatorial product. As the skew-boat is a higher energy conformation, this situation is disfavoured from a stereoelectronic point of view.

Carbapyranose 1,2-epoxides with the $\beta$-manno configuration 2 (Figure 1) were opened efficiently with attack at C1 (sterically and electronically favoured) to give 1,2-trans-diaxial [11] carba- $\alpha$-mannose derivatives with both oxygen [12] and nitrogen [13] nucleophiles. The electronic argument must be reformulated slightly in the absence of a Lewis acid. The localisation of electrons onto the leaving group (the epoxide oxygen) is necessary as the transition state is approached also under neutral or base-catalysed conditions [14]. Carbon $\mathrm{C} 2$ bears a $\beta$ electron-withdrawing group (the $\mathrm{C} 3$ benzyl ether), whereas $\mathrm{C} 1$ does not. Hence, from an electronic point of view, $\mathrm{S}_{\mathrm{N}} 2$ reactions should be more favourable at $\mathrm{C} 1$ than at $\mathrm{C} 2$. The same concept is a major factor in explaining the generally low reactivity of carbohydrates (at non-anomeric positions) in $\mathrm{S}_{\mathrm{N}} 2$ reactions. Carbapyranose 1,2-epoxides with $\alpha$-gluco 3 and $\alpha$-galacto configurations did not give such good results. With amine nucleophiles, attack was often unregioselective [15]: attack at C1 (favoured sterically and electronically) leads to stereoelectronically unfavourable [11] 1,2-trans-diequatorial opening. This nucleophilic dilemma presumably accounts for the poor regioselectivity and yields of such reactions. With alcohol nucleophiles, no coupling products were observed with either $\alpha$-gluco or $\alpha$-galacto carbapyranose 1,2-epoxides [16].

We considered the reactivity of a diastereomeric epoxide to the $\alpha$-galacto carbafuranose epoxide $\mathbf{1}$, i.e., a $\beta$-talo epoxide $\mathbf{4}$, in nucleophilic ring-opening reactions. The same steric and electronic arguments on regioselectivity would predict attack at $\mathrm{C} 1$ in the $\beta$-talo 1,2-epoxide 4. In 5-membered rings, nucleophilic attack at either carbon of an epoxide (with an envelope conformation) would result in a product with a twist-boat conformation, meaning that there was no great difference in energy between the two regioisomers as was the case in the 6-membered ring series, irrespective of the preferred envelope conformation of the epoxide, and that stereoelectronic effects are thus likely to be much less relevant for the more flexible cyclopentane derivatives. One factor that could speak against good regioselectivity in this case would be the fact that the $\alpha$-talo product has a 2,3-cis and 1,4-cis substituent pattern, which could lead to some strain in the transition state, whereas $\beta$-galacto derivatives have an all trans substituent pattern.

Should the epoxide-opening reaction proceed to give the $\alpha$-talo configured $\mathrm{C} 1$-substituted products, then this could offer a route to $\alpha$-configured galactofuranoside pseudodisaccharides via a subsequent epimerisation of the unprotected C2 alcohol, analogous to the $\alpha$-manno to $\alpha$-gluco epimerisation route developed by Ogawa in the six-membered ring series [17]. In this paper we report our results on the synthesis of carbasugar analogues of $\alpha$-galactofuranosides by this route.

Some related work in the form of ring opening of carbapentafuranose 1,2-epoxides has been reported in the area of carbanucleoside chemistry. Indeed, various $\alpha$-ribo configured carbasugar epoxides, which have the same configuration around the carbocyclic ring as the $\beta$-talo epoxide 4 , were opened by nitrogen nucleophiles (nucleobases [18] or azide [19,20]) with generally good regioselectivity for attack at $\mathrm{C} 1$. The only precedent for attack at such carbapentafuranose epoxides with an oxygen 
nucleophile would appear to be the acid-mediated attack of water on an $\alpha$-xylo configured epoxide, again with apparently good regioselectivity for attack at C1 [21].

\section{Results and Discussion}

Our synthesis of the $\beta$-talo 1,2-epoxide began from the $\beta$-galacto 1,2-diol 5 [22]. We needed to regioselectively transform $\mathrm{OH}-2$ into a leaving group that could then undergo intramolecular displacement by $\mathrm{O}-1$. The $\mathrm{OH}-1$ hydroxyl group appears to be more nucleophilic than $\mathrm{OH}-2$ in $\mathbf{5}$ [9]; a benzoate protecting group was introduced at $\mathrm{O}-1$ using a tin acetal method [23] to give the monobenzoate 6 with enhanced regioselectivity (Scheme 1). Only very small amounts $(<5 \%)$ of the regioisomer were observed and were not isolated in a pure form. The free $\mathrm{OH}-2$ could then be converted to its tosylate 7 . Treatment of this diester 7 with sodium methoxide resulted in<smiles>OC1C[C@H](C(COCc2ccccc2)OCc2ccccc2)C(O)C1O</smiles>

(i), (ii)<smiles>C#CC</smiles><smiles>BrOC1C2OC2CC1[C@@H](Br)C(Br)COc1ccccc1</smiles><smiles>O=C(OCc1ccccc1)OC1C[C@H](C(COc2ccccc2)OCc2ccccc2)C(O)[C@H]1O</smiles>

(iii)

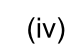

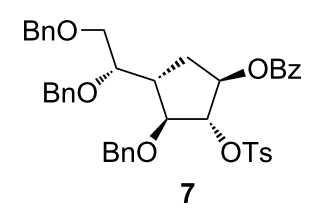

Scheme 1: (i) $\mathrm{Bu}_{2} \mathrm{SnO}, \mathrm{MeOH}, 70^{\circ} \mathrm{C}$; (ii) $\mathrm{BzCl}$, toluene, $82 \%$; (iii) $\mathrm{TsCl}$, py, $50{ }^{\circ} \mathrm{C}, 86 \%$; (iv) $\mathrm{NaOMe}, \mathrm{MeOH}, 81 \%$.

the direct formation of the required epoxide 4, presumably by cleavage of the $\mathrm{C} 1$ benzoate to the alcoholate (with retention of configuration) followed by intramolecular displacement of the C2 tosylate (with inversion of configuration). We synthesised the same epoxide 4 (78\%) by treatment of isolated 3,5,6-tri- $O$ benzyl-2- $O$-(toluene-4-sulfonyl)-4a-carba- $\beta$-D-galactofuranose [9] with sodium hydride in DMF.

We investigated ring-opening of the epoxide 4 by alcohol nucleophiles under Lewis acidic conditions as used in the diastereomeric series [9]. With excess ethanol (10 equiv), we obtained the $\mathrm{C} 1$ ethyl ether $\mathbf{8}$ as the major product (90\%) along with a small amount (4\%) of the regioisomer (Scheme 2$)$. The regiochemistry was proved by acetylation of the free alcohols. The major product 8 gave a $\mathrm{C} 2$ acetate $\mathbf{9}$, as shown by the downfield shift of $\mathrm{H} 2$ in the ${ }^{1} \mathrm{H}$ NMR spectrum, indicating nucleophilic attack at $\mathrm{C} 1$ during the epoxide-opening step to give an $\alpha$-talo configured product. The minor product gave a $\mathrm{C} 1$ acetate on acetylation, indicating attack at $\mathrm{C} 2$ in the epoxide opening and formation of a $\beta$-galacto product.

We then examined a secondary carbohydrate alcohol as the nucleophile. The mannose OH-3 nucleophile 10 [24] would lead to a structure corresponding to a $\operatorname{Gal} f(\alpha 1 \rightarrow 3) \operatorname{Man} p$ disaccharide substructure from the galactomannan from the fungus Apodus deciduus [6]. Here also, the epoxide 4 underwent ring opening with very good regioselectivity in favour of the C1-substituted ( $\alpha$-talo) product 11, which was isolated in $57 \%$ yield and characterised as its $C 2$ acetate 12. The regioisomeric $\mathrm{C} 2$-substituted ( $\beta$-galacto) product was not detected in the epoxide-opening reaction. In this reaction, a by-product 13 was also formed, which was characterised as its acetate $\mathbf{1 4}$ and assigned the structure given in Figure $2 \mathrm{a}$.<smiles>O=C(O)OC1C(O)C2OC2C[C@H]1[C@H](Br)OCc1ccccc1</smiles><smiles>C#CC</smiles>

$\beta$-talo 4<smiles>[R]O[C@H]1C[C@H]([C@H](COCc2ccccc2)OCc2ccccc2)[C@@H](O)[C@H]1O</smiles><smiles>[R]O[C@H]1C[C@H]([C@H](COc2ccccc2)OCc2ccccc2)[C@H](O)[C@H]1O</smiles>

(iii)<smiles>[R]O[C@H]1C[C@H]([C@H](COc2ccccc2)OCc2ccccc2)[C@H](O)C1=O</smiles>

15,16

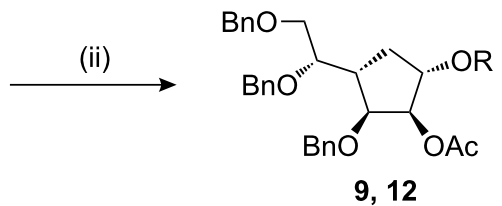

$\mathrm{R}=\mathrm{Et}$

$8,9,15,17$

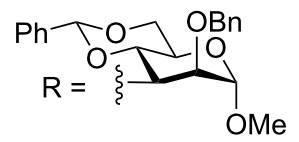

$10(\mathrm{ROH}), 11,12,16,18$ 
a)

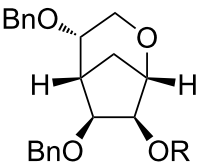

$13 \mathrm{R}=\mathrm{H}$

$14 \mathrm{R}=\mathrm{Ac}$ b)

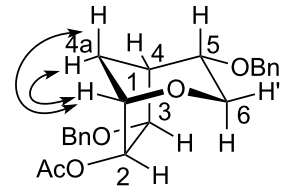

Result of attack at C1 Proposed structure 14 c)

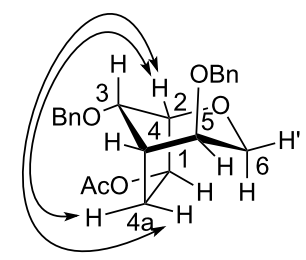

Result of attack at C2 Rejected structure 14x

Figure 2: a) Structures of 13 and 14; b) observed NOEs consistent with structure 14; c) observed NOEs inconsistent with structure 14x.

The ${ }^{1} \mathrm{H}$ NMR spectrum of the by-product 13 showed the presence of only two sets of characteristic signals for benzyl ethers, indicating that the third benzyl ether protecting group had been lost. The mass spectrum showed a peak at $\mathrm{m} / \mathrm{z} 363$, consistent with a bicyclic system. Acetylation with acetic anhydride and pyridine gave a monoacetate $\mathbf{1 4}$ according to NMR spectroscopy and mass spectrometry $(\mathrm{m} / \mathrm{z} 405)$.

We deduced the structure of the monoacetate 14 using NMR spectroscopy, including HSQC, HMBC and NOESY experiments. The $\mathrm{C} 1 / \mathrm{H} 1, \mathrm{C} 2 / \mathrm{H} 2$ and $\mathrm{C} 3 / \mathrm{H} 3$ pairings could not be easily distinguished due to the presence of some long-range couplings and correlations in the COSY spectra. One of these three carbons bore an acetate, as seen from the downfield shift of the corresponding proton. The second bore a benzyl ether, as shown by the $\mathrm{PhCH}_{2} \rightarrow \mathrm{C}$ cross-peaks in the HMBC spectrum. The third was linked to $\mathrm{C} 6$ by an ether, as seen from the $\mathrm{H} 6{ }^{\prime} \rightarrow \mathrm{C}$ cross-peak in the HMBC spectrum. The HMBC spectrum also revealed that $\mathrm{O}-5$ was still benzyl-ether-protected; hence, the benzyl ether was lost from O-6, presumably following nucleophilic attack by $\mathrm{O}-6$ on either $\mathrm{C} 1$ or $\mathrm{C} 2$ of the epoxide. The large difference in chemical shift between H6 (3.15 ppm) and H6' (3.90 ppm) is consistent with C6 being part of a rigid cyclic structure, rather than exocyclic.

The answer to the question of whether attack occurred at $\mathrm{C} 1$ or $\mathrm{C} 2$ required information from NOESY experiments. Attack at $\mathrm{C} 1$ would have led to 14 , whereas attack at $\mathrm{C} 2$ would have led to $14 \mathbf{x}$. The strongest support for the proposed structure was the NOE observed (Figure 2b) between H1 (if attack occurred at $\mathrm{C} 1$ ) and $\mathrm{H} 4 \mathrm{a}$ and $\mathrm{H} 4 \mathrm{a}$, which is consistent with structure 14; this would correspond to an NOE (Figure 2c) between H2 (if attack occurred at $\mathrm{C} 2$ ) and $\mathrm{H} 4 \mathrm{a}$ and $\mathrm{H} 4 \mathrm{a}$, which is not consistent with structure 14x. No NOE was seen between the acetylated $\mathrm{H}(\mathrm{H} 1$ or $\mathrm{H} 2)$ and $\mathrm{H} 4 \mathrm{a}$ or H4a': This supports structure 14 and essentially excludes the alternative structure $\mathbf{1 4 x}$. Finally, an NOE was observed between H6 (but not H6') and the acetylated $\mathrm{H}(\mathrm{H} 1$ or $\mathrm{H} 2)$, which allowed the $\mathrm{C} 6$ protons to be distinguished. H6 appeared as an apparent triplet with
$J 11 \mathrm{~Hz}$ in the ${ }^{1} \mathrm{H}$ NMR spectrum, which is consistent with a diaxial coupling to $\mathrm{H} 5$ as seen in structure $\mathbf{1 4}$, but not in $\mathbf{1 4 x}$.

Hence, compound $\mathbf{1 3}$ presumably arose from debenzylative cycloetherification by attack of O-6 on $\mathrm{C} 1, \mathrm{C} 1$ being the most electrophilic carbon in both inter- and intramolecular epoxideopening reactions.

To achieve the inversion of stereochemistry at $\mathrm{C} 2$ of the $\alpha$-talo carbasugars, our best results were obtained using an oxidation-reduction approach. Attempted $\mathrm{S}_{\mathrm{N}} 2$ reactions (Mitsunobu reaction or sulfonate displacement) gave inferior results. Hence the $\mathrm{C} 2$ alcohols $\mathbf{8}$ and $\mathbf{1 1}$ were oxidised under Swern conditions to give the ketones $\mathbf{1 5}$ and 16. Reduction of ketone group in ethyl ether $\mathbf{1 5}$ with sodium borohydride gave a rather poor diastereoselectivity. However, using L-selectride excellent selectivity for the formation of the required $\alpha$-galacto carbasugar 17 (78\% isolated) was observed; the $\alpha$-talo product $\mathbf{8}$ was also formed, but not in sufficient quantity that it could be isolated in a pure state. The pseudodisaccharide ketone $\mathbf{1 6}$ was also then reduced with L-selectride, again very good diastereoselectivity for the $\alpha$-galacto configured carbasugar $\mathbf{1 8}$ was observed.

\section{Conclusion}

Complementing our approach to $\beta$-configured $O$-linked galactofuranosides by epoxide ring opening, the corresponding $\alpha$-compounds can be made by an indirect route: Opening of a $\beta$-talo configured epoxide followed by $\mathrm{C} 2$ epimerisation. The very good regioselectivity in the epoxide-opening reaction indicates that steric and/or electronic effects favouring attack at $\mathrm{C} 1$ over $\mathrm{C} 2$ are more important than other factors; the difference in efficiency of the "up" ( $\beta$-manno) and "down" ( $\alpha$-gluco) carbapyranose 1,2-epoxides in coupling reactions was not observed in the carbafuranose series. It is possible that this strategy for pseudodisaccharide formation by epoxide ring opening in the ( $\alpha$ and $\beta$ ) carbagalactofuranose series could be extended to the pseudoenantiomeric ( $\beta$ and $\alpha$ ) carbaarabinofuranose series [25], which represent similarly relevant biological targets [26]. 


\section{Supporting Information}

Supporting information features experimental section and NMR spectra for new compounds.

\section{Supporting Information File 1}

Experimental and NMR data.

[http://www.beilstein-journals.org/bjoc/content/ supplementary/1860-5397-6-129-S1.pdf]

\section{Supporting Information File 2}

NMR spectra.

[http://www.beilstein-journals.org/bjoc/content/ supplementary/1860-5397-6-129-S2.pdf]

\section{Acknowledgement}

Financial support from Vetenskapsrådet (the Swedish research council) is gratefully acknowledged.

\section{References}

1. Peltier, P.; Euzen, R.; Daniellou, R.; Nugier-Chauvin, C.; Ferrières, V. Carbohydr. Res. 2008, 343, 1897-1923.

doi:10.1016/j.carres.2008.02.010

2. Richards, M. R.; Lowary, T. L. ChemBioChem 2009, 10, 1920-1938. doi:10.1002/cbic.200900208

3. Bock, K.; Pedersen, C. Adv. Carbohydr. Chem. Biochem. 1983, 41, 27-66. doi:10.1016/S0065-2318(08)60055-4

4. Cyr, N.; Perlin, A. S. Can. J. Chem. 1979, 57, 2504-2511. doi:10.1139/v79-399

5. Gupta, A. K.; BeMiller, J. N. Phytochemistry 1990, 29, 853-855. doi:10.1016/0031-9422(90)80032-C

6. Ahrazem, O.; Prieto, A.; Leal, J. A.; Jiménez-Barbero, J.; Bernabé, M. Carbohydr. Res. 2002, 337, 1503-1506. doi:10.1016/S0008-6215(02)00184-2

7. Yang, Y.-L.; Yang, F.-L.; Huang, Z.-Y.; Tsai, Y.-H.; Zou, W.; Wu, S.-H. Org. Biomol. Chem. 2010, 8, 4252-4254. doi:10.1039/c0ob00169d

8. Pettit, G. R.; Xu, J.-P.; Gingrich, D. E.; Williams, M. D.; Doubek, D. L.; Chapuis, J.-C.; Schmidt, J. M. Chem. Commun. 1999, 915-916. doi:10.1039/a902380a

9. Frigell, J.; Cumpstey, I. Tetrahedron Lett. 2009, 50, 5142-5144. doi:10.1016/j.tetlet.2009.06.115

10. Cumpstey, I. Carbohydr. Res. 2009, 344, 2285-2310. doi:10.1016/j.carres.2009.09.008

11. Fürst, A.; Plattner, P. A. Helv. Chim. Acta 1949, 32, 275-283. doi:10.1002/hlca.19490320139

12. Ogawa, S.; Sasaki, S.-I.; Tsunoda, H. Chem. Lett. 1993, 1587-1590. doi:10.1246/cl.1993.1587

13. Ogawa, S.; Sasaki, S.-I.; Tsunoda, H. Carbohydr. Res. 1995, 274, 183-196. doi:10.1016/0008-6215(95)00121-9

14. Shaik, S. S. J. Am. Chem. Soc. 1983, 105, 4359-4367. doi:10.1021/ja00351a039

15. Ogawa, S.; Hirai, K.; Yamazaki, T.; Nakajima, A.; Matsunaga, N. Carbohydr. Lett. 1996, 2, 183-188.
16. Ogawa, S.; Hirai, K.; Odagiri, T.; Matsunaga, N.; Yamazaki, T.; Nakajima, A. Eur. J. Org. Chem. 1998, 1099-1109. doi:10.1002/(SICl)1099-0690(199806)1998:6<1099::AID-EJOC1099>3 .0.CO;2-R

17. Ogawa, S.; Ohmura, M.; Hisamatsu, S. Synthesis 2001, 312-316. doi:10.1055/s-2001-10800

18. Hutchison, A.; Grim, M.; Chen, J. J. Heterocycl. Chem. 1989, 26, 451-452. doi:10.1002/jhet.5570260235

19. Palmer, C. F.; Parry, K. P.; Roberts, S. M. Tetrahedron Lett. 1990, 31 , 279-282. doi:10.1016/S0040-4039(00)94392-2

20. Paulsen, H.; Maass, U. Chem. Ber. 1981, 114, 346-358.

21. Marschner, C.; Baumgartner, J.; Griengl, H. J. Org. Chem. 1995, 60, 5224-5235. doi:10.1021/jo00121a046

22. Frigell, J.; Cumpstey, I. Tetrahedron Lett. 2007, 48, 9073-9076. doi:10.1016/j.tetlet.2007.10.138

23. Grindley, T. B. Adv. Carbohydr. Chem. Biochem. 1998, 53, 17-142. doi:10.1016/S0065-2318(08)60043-8

24. Ennis, S. C.; Cumpstey, I.; Fairbanks, A. J.; Butters, T. D.; Mackeen, M.; Wormald, M. R. Tetrahedron 2002, 58, 9403-9411. doi:10.1016/S0040-4020(02)01221-8

25. Callam, C. S.; Lowary, T. L. J. Org. Chem. 2001, 66, 8961-8972. doi:10.1021/jo010827r

26. Joe, M.; Bai, Y.; Nacario, R. C.; Lowary, T. L. J. Am. Chem. Soc. 2007, 129, 9885-9901. doi:10.1021/ja072892+

\section{License and Terms}

This is an Open Access article under the terms of the Creative Commons Attribution License (http://creativecommons.org/licenses/by/2.0), which permits unrestricted use, distribution, and reproduction in any medium, provided the original work is properly cited.

The license is subject to the Beilstein Journal of Organic Chemistry terms and conditions:

(http://www.beilstein-journals.org/bjoc)

The definitive version of this article is the electronic one which can be found at: doi:10.3762/bjoc.6.129 